\title{
PENGARUH KINERJA KEUANGAN \\ DAN BELANJA MODAL TERHADAP PERTUMBUHAN EKONOMI PADA KABUPATEN/KOTA DI JAWA TENGAH
}

\author{
Istia Nur Pradiatmi, HardiyantoWibowo \\ Program Studi Akuntansi Fakultas Ekonomi dan Bisnis \\ Universitas Muhammadiyah Purwokerto \\ Email: istia.mutia@gmail.com
}

\begin{abstract}
This research was quantitative research that aims to determine the effect of financial such as the ratio of decentralization degree, the dependency ratio, the independent ratio, effectiveness ratio, the ratio of the contribution degree of Regional Owned Enterpise (BUMD), efficiency ratio, and the ratio of expenditure harmony as well as capital expenditure to economic growth. The population of the study was the regencies/cities in Central Java. The sample of study were selected using census method and obtained 175 observation sample. The analysis technique applied in this reseach was multiple linear regretion analysis. This analysis proved that the ratio of variable degree of decentralization positively and significantly affected on economic growth with significant score of 0,009 <0,05. Dependency ratio variable significantly and negatively affected on economic growth with significant score of 0,004 <0,05. Independent ratio variable significantly and negatively affected on economic growth with significant score of 0,000 $<0,05$. Effectiveness ratio variable did not affect the economic growth with significant score of $0,240>0,05$. The degree of regional owned enterpise contribution variable did not affect the economic grow th with significant score of 0,454 >0,05. Efficiency ratio variable did not affect the economic growth with significant score of 0,419 $>0,05$. Ratio variable of compatible expenditure did not affect the economic growth with significant score of 0,341 >0,05. However, the capital expenditure variable did not affect the economic growth with significant score of 0,098 >0,05.
\end{abstract}

Keyword: financial performance, capital expenditure, and economic growth

\section{PENDAHULUAN}

Otonomi daerah merupakan pemberdayaan dalam pengambilan keputusan secara lebih leluasa untuk mengelola sumber daya yang dimiliki oleh masingmasing daerahsesuai dengan kepentingan, prioritas dan potensi daerah yang dimiliki. Hal ini sesuai dengan UU No. 23 tahun 2014 dan Undang-Undang No. 33 Tahun 2004 yang menjadi landasan penyelenggaraan dan pelaksanaan otonomi daerah. Kemampuan pemerintah daerah dalam mengelola keuangan daerah sangat mempengaruhi kemajuan dan nasib daerah tersebut.Dalam Peraturan Pemerintah No. 58 Tahun 2005 tentang Pengelolaan Keuangan Daerah, disebutkan bahwa keuangan daerah adalah semua hak dan kewajiban dalam rangka penyelenggaraan pemerintah daerah yang dapat dinilai dengan uang termasuk didalamnya segala bentuk kekayaan yang berhubungan dengan hak dan kewajiban daerah tersebut.

Terwujudnya pengelolaan keuangan yang efektif dan efisien salah satunya dapat diukur melalui besarnya pendapatan daerah tersebut, khususnya Pendapatan Asli Daerah (PAD). PAD yang diterima oleh pemerintah selanjutnya akan digunakan dalam belanja pemerintahyang diharapkan dapat mempengaruhi pertumbuhan ekonomi pada suatu daerah (Arsa, 2015).Hal ini disebabkan oleh belanja modal yang dianggarkan dapat digunakan sebagai investasi daerah yang menjadi

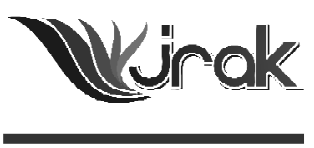

Jurnal Reviu Akuntansi dan Keuangan

ISSN: 2088-0685 Vol.5 No. 2, Oktober 2015 Pp 759-768 


\section{Pengaruh Kinerja \\ Keuangan...}

760

salah satu faktor yang mempengaruhi pertumbuhan ekonomi selain pertumbuhan penduduk dan kemajuan teknologi(Prihastuti, 2015). Upaya pemerintah daerah dalam menggali kemampuan daerah dapat dilihat dari kinerja keuangan daerah. Dalam mengukur kinerja keuangan pemerintah dearah dilakukan dengan menggunakan rasio derajat desentralisasi, rasio ketergantungan keuangan, rasio kemandirian keuangan daerah, rasio efektifitas, rasio derajat kontribusi BUMD, rasio efisiensi, rasio keserasian belanja, rasio pertumbuhan, rasio likuiditas, rasio solvabilitas, DSCR (Debt Service Coverage Ratio) dan rasio belanja terhadap PDRB (Sularso, 2011).

Suatu daerah dianggap berhasil dalam mengelola keuangan daerah, apabila kinerja keuangan pada pemerintah daerah tersebut dikategorikan baik. Pengelolaan keuangan daerah yang dilakukan secara ekonomis, efisien, dan efektif atau memenuhi prinsip value for money serta partisipasi, transparasi, akuntabilitas, dan keadilan yang dapat mendorong pertumbuhan ekonomi (Sularso, 2011). Kemajuan suatu daerah juga dapat dilihat salah satunya dari rasio pertumbuhan ekonomi yang baik. Pertumbuhan ekonomi merupakan kemampuan suatu daerah dalam menyediakan akan barang dan jasa kepada masyarakat dengan jumlah yang banyak, sehingga memungkinkan untuk menaikan standar hidup. Tolak ukur pertumbuhan ekonomi suatu daerah adalah Pendapatan Domestik Regional Bruto yang tidak bisa lepas dari peran pengeluaran pemerintah terutama investasi daerah dalam sektor publik. Alokasi belanja modal yang dilakukan oleh pemerintah tersebut juga dipengaruhi oleh baik atau tidaknya kinerja keuangan pemerintah daerah (Sularso, 2011). Dengan demikian, terdapat keterkaitan antara kinerja keuangan, belanja modal dan pertumbuhan ekonomi.

Berdasarkan uraian latar belakang diatas, maka masalah yang akan diteliti adalah apakah derajat desentralisasi, kemandirian keuangan daerah, efektifitas $\mathrm{PAD}$, derajat kontribusi BUMD, rasio efisiensi, rasio keserasian belanja, dan belanja modal berpengaruh positif terhadap pertumbuhan ekonomi dan apakah ketergantungan keuangan berpengaruh negatif terhadap pertumbuhan ekonomi. Tujuan dari penelitian ini adalah untuk mengetahui pengaruh derajat desentralisasi, ketergantungan keuangan, kemandirian keuangan daerah, efektifitas PAD, derajat kontribusi BUMD, rasio efisiensi, rasio keserasian belanja, dan belanja modal terhadap pertumbuhan ekonomi.

\section{Kinerja keuangan}

Kinerja merupakan hasil kerja yang telah dicapai dari pelaksanaan suatu kegiatan, baik oleh pribadi maupun organisasi (Sujarweni, 2015). Menurut Halim (2008) analisis keuangan adalah usaha mengidentifikasi ciri-ciri keuangan berdasarkan laporan keuangan yang tersedia. Dalam pengukuran kinerja keuangan dan pengaruhnya terhadap pertumbuhan ekonomi hanya ada tujuh rasio yang dipakai yaitu :

\section{Rasio Derajat Desentralisasi}

Desentralisasi fiskal dapat diukur dengan rasio derajat desentralisasi yang menunjukkan seberapa jauh kemampuan pemerintah daerah dalam menyelenggarakan desentalisasi(Rosdyana, 2015). Rasio ini dapat dihitung dengan formula:

$$
\text { Derajat Desentralisasi }=\frac{P A D}{\text { Total Pendapatan Daera } h} X 100 \%
$$

\section{Rasio Ketergantungan Keuangan}

Rasio ketergantungan keuangan merupakan rasio yang menunujukkan seberapa besar tingkat ketergantungan keuangan suatu daerah terhadap pemerintah pusat atau pemerintah provinsi. Semakin tinggi rasio ini, maka tingkat keter- 
gantungan pemerintah daerah terhadap pemerintah pusat atau provinsi semakin besar (BPKP, 2012 dalam Arsa, 2015).Rasio ketergantungan keuangan dihitung dengan rumus:

$$
\text { Rasio ketergantungan }=\frac{\text { PendapatanTransfer }}{\text { TotalPendapatandaera }} \quad \text { h } 100 \%
$$

\section{Rasio Kemandirian Daerah}

Rasio kemandirian menggambarkan tingkat ketergantungan daerah terhadap sumber dana eksternal. Semakin tinggi rasio kemadiriannya, maka tingkat ketergantungan daerah terhadap bantuan pihak eksternal (terutama pemerintah pusat dan provinsi) semakin rendah dan sebaliknya (Halim, 2008). Rasio kemandirian keuangan dihitung dengan rumus:

$$
\text { Rasio kemandirian }=\frac{\text { Pendapatan Asli Daera } h}{\text { Dana Perimbangan }+ \text { Pinjaman Daera } h} X 100 \%
$$

\section{Rasio Efektifitas}

Rasio efektifitas menggambarkan kemapuan pemerintah daerah dalam merealisasikan Pendapatan Asli Daerah (PAD) yang sudah direncanakan dibandingkan dengan target yang ditetapkan berdasarkan potensi riil daerah. Dikatakan efektif jika hasilnya $100 \%$. Semakin tinggi rasio efektifitasnya, maka kemampuan pemerintah pun semakin baik. (Halim, 2008). Rasio efektifitas dihitung dengan rumus:

$$
\text { Rasio Efektifitas PAD }=\frac{\text { Realisasi } P A D}{\text { Target } P A D} \times 100 \%
$$

\section{Rasio derajat Kontribusi BUMD}

Derajat kontribusi BUMD digunakan untuk mengetahui tingkat kontribusi perusahaan daerah dalam mendukung pendapatan daerah (BPKP, 2012 dalam Arsa, 2015). Rasio ini dapat dihitung dengan rumus:

$$
\text { Derajat distribusi BUMD }=\frac{\text { Penerimaan bagian laba BUMD }}{\text { Penerimaan } P A D} X 100 \%
$$

\section{Rasio Efisiensi}

Rasio efisiensi adalah rasio yang menggambarkan perbandingan antara besarnya biaya yang dikeluarkan untuk memperoleh pendapatan dengan realisasi pendapatan yang diterima. Semakin kecil rasio efisiensi, berarti kinerja pemerintah daerah semakin baik dan sebaliknya. Kinerja pemerintah daerah dikatakan efisien apabila rasio yang dicapai $<100 \%$ (Halim, 2008). Rasio efisiensi dalam dihitung dengan rumus:

$$
\text { Rasio efisiensi }=\frac{\text { Realiasasi Belanja }}{\text { Realisasi Penerimaan PAD }} \times 100 \%
$$

\section{Rasio Keselarasan Belanja}

Rasio keserasian belanja menggambarkan bagaimana pemeintah daerah memprioritaskan alokasi dananya pada belanja rutin dan belanja pembangunan secara optimal. Semakin tinggi persentase dana yang dialokasikan untuk belanja rutin, berarti persentase belanja investasi yang digunakan untuk menyediakan sarana dan prasarana ekonomi masyarakat masyarakat cenderung semakin kecil (Halim, 2008). Rasio keserasian belanja ini dihitung dengan rumus: 


\section{Pengaruh \\ Kinerja \\ Keuangan...}

762
Rasio keserasian belanja $=\frac{\text { Total Belanja Pembangunan }}{\text { Total APBD }} X 100 \%$

\section{Belanja modal}

Belanja modal adalah pengeluaran yang dilakukan dalam rangka pembentukan modal yang sifatnya menambah aset tetap/inventaris yang memberikan manfaat lebih dari satu periode akuntansi, termasuk didalamnya adalah pengeluaran untuk biaya pemeliharaan yang sifatnya mempertahankan atau menambah masa manfaat, meningkatkan kualitas dan kapsitas aset.Belanja modal dihitung dengan formula:

Belanja Modal = Belanja Tanah + Peralatan dan Mesin + Gedung dan Bangunan + Jalan, Irigasi dan Jaringan + Aset tetap lainnya + Konstruksi Dalam Pengerjaan + Aset Lainnya.

\section{Pertumbuhan ekonomi}

Pertumbuhan ekonomi dapat diartikan sebagai peningkatan kegiatan ekonomi pada suatu daerah yang akan berdampak pada tingkat kemakmuran dan kemandirian masyarakat di suatu daerah. Salah satu faktor yang mendorong semakin tingginya kemampuan keuangan daerah adalah pertumbuhan ekonomi (Sasana, 2009). Pertumbuhan ekonomi dapat dihitung dengan laju pertumbuhan PDRB dengan formula sebagai berikut:

$$
G=\frac{P D R B_{t}-P D R B_{t-1}}{P D R B_{t-1}} X 100 \%
$$

\section{Kerangka Pemikiran}

Pengelolaan keuangan yang baik dapat ditunjukakan dengan kinerja keuangan yang baik pula. Apabila kinerja keuangan pemerintah daerah baik akan berpengaruh kepada peningkatan pendapatan daerah sehingga dapat mempengaruhi proporsi belanja modal yang dianggarkan dalam APBD. Belanja modal ini dapat digunakan untuk investasi daerah yang menjadi salah satu faktor yang memperngaruhi pertumbuhan ekonomi suatu daerah selain pertumbuhan penduduk dan kemajuan teknologi. Berdasarkan penjelasan di atas, skematis model kerangka pemikiran sebagai berikut:

Hipotesis

$\mathrm{H}_{1}$ : Derajat Desentralisasi berpengaruh positif terhadap pertumbuhan ekonomi.

$\mathrm{H}_{2}$ : Ketergantungan keuangan berpengaruh negatif terhadap pertumbuhan ekonomi.

$\mathrm{H}_{3}$ : Kemandirian keuangan daerah berpengaruh positif terhadap pertumbuhan ekonomi.

$\mathrm{H}_{4}$ : Efektifitas PAD berpengaruh positif terhadap pertumbuhan ekonomi.

$\mathrm{H}_{5}$ : Derajat kontribusi BUMD berpengaruh positif terhadap pertumbuhan ekonomi.

$\mathrm{H}_{6}$ : Rasio Efisiensi berpengaruh positif terhadap pertumbuhan ekonomi.

$\mathrm{H}_{7}$ : Keserasian belanja berpengaruh positif terhadap pertumbuhan ekonomi.

$\mathrm{H}_{8}$ : Belanja modal berpengaruh positif terhadap pertumbuhan ekonomi.

\section{METODE PENELITIAN}

Penelitian ini merupakan jenis penelitian kuantitatif. Populasi yang digunakan dalam penelitian ini adalah laporan APBD Kabupaen/kota di Jawa Tengah 
beserta realisasinya dan data pertumbuhan ekonomi Kabupaten/kota di Jawa Tengah tahun 2010-2014. Penelitian ini menggunakan teknik total sampling (sensus) dengan sampel 35 Kabupaten/kota di Jawa Tengah. Metode pengumpulan data yang dilakukan adalah melalui metode pencatatan dokumen. Metode ini menggunakan data sekunder yang diperoleh dari website www.djpk.depkeu. go.iddan BPS (www.jateng.bps.go.id). Data tersebut adalah data laporan APBD beserta realisasinya dan laju pertumbuhan ekonomi.

\section{HASIL DAN PEMBAHASAN}

\section{Statistik deskriptif}

Hasil Statistik deskriptif terdapat pada tabel 4.3 yang menjelaskan bahwa pertumbuhan ekonomi tertinggidi kota Semarang tahun 2014 sebesar 6,64\% dan terendah di Kabupaten Demak tahun 2010 sebesar 4,12\%. Rasio derajat desentralisasi yang tertinggi di kota Semarang tahun 2014 sebesar 35,96\% dan terendah di Kabupaten Klaten tahun 2011 sebesar 5,30\%. Rasio ketergantungan tertinggi di Kabupaten Pekalongan tahun 2012 sebesar 97,76\% dan terendah di dari kota Semarang tahun 2014 sebesar $61,85 \%$.

\begin{tabular}{lrrrrr}
\hline & N & Minimum & Maximum & \multicolumn{1}{c}{ Mean } & Std. Deviation \\
\hline PE & 146 & 4,12 & 6,64 & 5,3391 & 0,57920 \\
RDD & 146 & 5,30 & 35,96 & 11,8528 & 5,38995 \\
RKK & 146 & 61,85 & 97,76 & 84,6723 & 5,97608 \\
RKD & 146 & 7,17 & 197,59 & 19,8187 & 19,14688 \\
Refts & 146 & 81,89 & 197,59 & 112,8125 & 14,13245 \\
RDK & 146 & 0,67 & 12,17 & 4,8336 & 2,40059 \\
RE & 146 & 259,80 & 1821,41 & 940,8730 & 326,09422 \\
RKB & 146 & 31,15 & 2517,76 & 148,9113 & 212,15826 \\
BM & 146 & 254787670 & 86363572161 & 2413104249 & 709876931514,4 \\
Valid N & & 23,00 & 00,00 & 72,2110 & 6610 \\
(listwise) & 146 & & & & \\
\hline
\end{tabular}

Sumber: Data yang diolah, 2017

\section{Uji Asumsi Klasik \\ Uji Normalitas}

Berdasarkan pengujian menunjukkan bahwa data berdistribusi normal. Hal ini ditunjukkan dengan hasil uji Kolmogorov-Smirnovdengan nilai signifikansi sebesar $0,656>0,05$.

\section{Uji Multikolinearitas}

Berdasrkan hasil pengujian multikolinearitas menunjukkan bahwa data bebas dari multikolinearitas. Hal ini ditunjukkan dengan nilai toleance yang dihasilkan setiap variabel independen $\geq 0,10$ dan nilai $\mathrm{VIF} \leq 10$.

\section{Uji Heterokedastisitas}

Berdasarkan hasil pengujian menunjukkan bahwa data bebas dari heterodekastisitas. Hal ini ditunjukkan dengan nilai signifikansi setiap variabel independen $>0,05$.
Tabel 1.

Hasil Uji Statistik Deskriptif 


\section{Pengaruh \\ Kinerja \\ Keuangan...}

764

\section{Uji Autokorelasi}

Berdasarkan hasil pengujian diketahui nilai dw sebesar 2,153. Nilai dl sebesar 1,6122 sedangkan nilai du sebesar 1,8461 dan nilai 4 - du sebesar 2,1539, sehingga dapat disimpulkan bahwa du $<\mathrm{d}<4$ - du dengan keputusan tidak ditolak yang berarti bahwa data tersebut bebas dari autokorelasi.

\section{Uji Statistik F}

Berdasarkan hasil pengujian diketahui bahwa nilai signifikansi sebesar 0,001 $<0,05$. Dengan demikian dapat disimpulkan bahwa model persamaan regresi yang digunakan layak digunakan sebagai model penelitian.

\section{Uji Analisis Regresi Berganda} berikut:

Berdasarkan tabel 4.14, dapat disusun persamaan regresi berganda sebagai

$$
\begin{aligned}
\mathrm{PE}= & 7,806+0,053 \mathrm{RDD}+-0,039 \mathrm{RKK}+-0,025 \mathrm{RKD}+0,005 \mathrm{REfts}+ \\
& -0,017 \mathrm{RDK}+0,000 \mathrm{RE}+0,000 \mathrm{RKB}+2,063 \mathrm{E}-013 \mathrm{BM}+\mathrm{e}
\end{aligned}
$$

\begin{tabular}{|c|c|c|c|c|c|c|}
\hline & \multirow[t]{2}{*}{ Model } & \multicolumn{2}{|c|}{ Unstandardized Coefficients } & \multirow{2}{*}{$\begin{array}{r}\text { Standardized } \\
\text { Coefficients } \\
\text { Beta } \\
\end{array}$} & \multirow[t]{2}{*}{$\mathrm{t}$} & \multirow[t]{2}{*}{ Sig. } \\
\hline & & B & Std. Error & & & \\
\hline \multirow{9}{*}{1} & (Constant) & 7,806 & 1,334 & & 5,850 &, 000 \\
\hline & RDD & ,053 &, 020 & ,494 & 2,633 & ,009 \\
\hline & RKK &,- 039 & 013 &,- 593 & $-2,908$ & ,004 \\
\hline & RKD &,- 025 & 007 &,- 837 & $-3,640$ & 000 \\
\hline & Refts & 005 & ,004 & ,115 & 1,180 & 240 \\
\hline & RDK &,- 017 & 023 &,- 072 &,- 751 & ,454 \\
\hline & RE & ,000 & 000 & ,137 & ,811 & ,419 \\
\hline & RKB & 000 & 000 &,- 077 &,- 955 & ,341 \\
\hline & BM & 2,063E-013 & 000 &, 132 & 1,668 & ,098 \\
\hline
\end{tabular}

Sumber: Data yang diolah, 2017

Tabel 2. Uji Statistik t

\section{PEMBAHASAN}

\section{Hasil Pengujian Hipotesis Pertama}

Berdasarkan hasil pengujian diketahui bahwa nilai koefisien 0,494 dengan arah positif dan nilai signifikansi $0,009<0,05$ sehingga disimpulkan bahwa hipotesis pertama yang menyatakan bahwa rasio derajat desentralisasi berpengaruh positif terhadap pertumbuhan ekonomi diterima.Hal ini dikarenakan meningkatnya pendapatan masyarakat yang menjadikan tingkat daya beli meningkat, sehingga meningkatkan penerimaan PAD maka semakin besar pula penerimaan daerah yang dapat dialokasikan pada sumber daya di sektor publik yang lebih luas lagi terutama pada investasi yang nantinya akan meningkatkan pertumbuhan ekonomi(Rosyana, 2015).

\section{Hasil Pengujian Hipotesis Kedua}

Berdasarkan hasil pengujian diketahui bahwa nilai koefisien sebesar -0,593 dengan arah negatif dan nilai signifikansi sebesar 0,004<0,05 sehingga disimpulkan bahwa hipotesis kedua yang menyatakan rasio ketergantungan keuangan berpengaruh negatif terhadap pertumbuhan ekonomi diterima. Hal ini dikarenakansemakin rendah rasio ketergantungan keuangan berarti pemerintah daerah dapat melaksanakan desentralisasi fiskal dengan baik, sehingga pendapat- 
an daerah menjadi maksimal, maka alokasi belanja rutin dapat dipenuhi dan dapat membelanjakannya untuk investasi daerah yang akan meningkatkan pertumbuhan ekonomi.

\section{Hasil Pengujian Hipotesis Ketiga}

Berdasarkan hasil pengujian diketahui bahwa nilai koefisien sebesar -0,837 dengan arah negatif dan nilai signifikansi sebesar $0,000<0,05$ sehingga disimpulkan bahwa hipotesis ketiga yang menyatakan rasio kemandirian keuangan daerah berpengaruh positif terhadap pertumbuhan ekonomi ditolak. Hal ini dikarenakanrealisasi pendapatan asli daerah jumlahnya kecil dan dana perimbangan dari pemerintah pusat jumlahnya lebih besar dari realiasasi pendapatan asli daerahnya pada masing-masing daerah. Sehingga dapat dikatakan pemerintah daerah belum maksimal dalam mengelola dan menggali potensi daerah berdasarkan kondisi riil daerah tersebut.

\section{Hasil Pengujian Hipotesis Keempat}

Berdasarkan hasil pengujian diketahui bahwa nilai koefisien sebesar 0,115 dengan arah positif dan nilai signifikansi sebesar 0,240>0,05 sehingga disimpulkan bahwa hipotesis keempat yang menyatakan rasio efektifitas berpengaruh positif terhadap pertumbuhan ekonomi ditolak. Hal ini dikarenakanrealisasi penerimaan pendaptan asli daerah dibandingkan dengan target penerimaan atau anggaran yang dialokasikan masing-masing daerah tidak terlalu signifikan. Dengan demikian dapat dikatakan bahwa tidak memenuhi ekonomis, efisiensi, dan efektif (value for money), bahkan terdapat kabupaten yang tidak mencapai target pendapatan asli daerah yang telah ditetapkan, sehingga rasio ini kurang mampu dalam mendorong terjadinya pertumbuhan ekonomi.

\section{Hasil Pengujian Hipotesis Kelima}

Berdasarkan hasil pengujian diketahui bahwa nilai koefisien sebesar -0,072 dengan arah negatif dan nilai signifikansi sebesar 0,454>0,05 sehingga disimpulkan bahwa hipotesis kelima yang menyatakan rasio derajat kontribusi BUMD berpengaruh positif terhadap pertumbuhan ekonomi ditolak. Hal ini dikarenakanrendahnya realissi bagi laba BUMD dengan realisasi pendaptan daerah secara keseluruhan oleh masing-masing daerah. Akibatnya penerimaan pendapatan asli daerah tidak maksimal yang berdampak pada tingkat kontribusi PAD terhadap pendapatan daerah secara keseluruhan kecil persentasenya, sehingga rasio ini kurang mampu untuk mendorong adanya pertumbuhan ekonomi.

\section{Hasil Pengujian Hipotesi Keenam}

Berdasarkan hasil pengujian diketahui bahwa nilai koefisien sebesar 0,137 dengan arah positif dan nilai signifikansi sebesar 0,419>0,05 sehingga disimpulkan bahwa hipotesis keenam yang menyatakan rasio efisiensi berpengaruh positif terhadap pertumbuhan ekonomi ditolak. Hal ini dikarenakan adanya realisasi belanja terlalu besar dibandingkan dengan realisasi penerimaan pendapatannya yang menyebabkan terjadinya kekurangan anggaran dan tidak adapat dialokasikan untuk belanja publik. Hal ini menunjukkan adanya inefisiensi, sehingga sebagian anggaran yang dialokasikan tidak dapat mendorong pertumbuhan ekonomi.

\section{Hasil Pengujian Hipotesis Ketujuh}

Berdasarkan hasil pengujian diketahui bahwa nilai koefisien sebesar -0,077 dengan arah negatif dan nilai signifikansi sebesar 0,341>0,05 sehingga disimpulkan bahwa hipotesis ketujuh yang menyatakan rasio keserasian belanja (rasio aktifitas ) berpengaruh positif terhadap pertumbuhan ekonomi ditolak.Hal ini 
Pengaruh

Kinerja

Keuangan...

dikarenakan pengeluaran untuk belanja pembangunan lebih besar dibandingkan dengan total APBD yang dialokasikan oleh pemerintah daerah. Hal ini menyebabkan pemerintah daerah menjadi ketergantungan dengan pihak lain serta menjadikan anggaran tidak dialokasikan untuk belanja yang lain, sehingga rasio ini tidak mampu untuk mendorong terjadinya pertumbuhan ekonomi.

\section{Hasil Pengujian Hipotesis Kedelapan}

Berdasarkan hasil pengujian diketahui bahwa nilai koefisien sebesar 0,132 dengan arah positif dan mempunyai nilai signifikansi sebesar 0,098>0,05 sehingga disimpulkan bahwa hipotesis kedelapan yang menyatakan belanja modal berpengaruh positif terhadap pertumbuhan ekonomi ditolak. Hal in dikarenakan jumlah belanja modal yang besar tidak sebanding dengan jumlah pendapatan daerah yang mengakibatkan pemerintah daerah memerlukan pinjaman atau dana transfer yang lebih besar serta belanja rutin pemerintah yang besar pula yang menjadikan pemerintah daerah tidak optimal dalam membelanjakan anggaran belanja pembangunannya. Sehingga belanja modal kurang mendorong pertumbuhan ekonomi.

\section{KESIMPULAN DAN SARAN}

Berdasarkan hasil penelitian dan pembahasan diatas dapat disimpulkan bahwa : 1. Rasio derajat desentralisasi berpengaruh positif terhadap pertumbuhan ekonomi pada kabupaten/kota di Jawa Tengah, 2. Rasio ketergantungan keuangan berpengaruh negatif terhadap pertumbuhan ekonomi pada kabupaten/kota di Jawa Tengah, 3. Rasio kemandirian keuangan daerah, rasio efektifitas, rasio derajat kontribusi BUMD, rasio efisiensi, rasio keserasian belanja, dan belanja modal tidak berpengaruh positif terhadap pertumbuhan ekonomi pada kabupaten/kota di Jawa. Keterbatasan dalam penelitian ini adalah sebagai berikut:1. Pada penelitian ini variabel independen meneliti hanya 8 (delapan) variabel saja, masih banyak variabel lainnya yang tidak diteliti yang mungkin mempengaruhi lebih kuat lagi variabel dependen, 2. Pada penelitian ini peneliti hanya menggunakan data sekunder belum melakukan observasi secara langsung seperti survei kuisioner atau wawancara, 3. Pada penelitian ini peneliti hanya menggunakan periodesasi 5 (lima) tahun dari tahun 2010-2014.Berdasarkan hasil penelitian serta keterbatasan penelitian diatas peneliti menyarankan agar penelitian selanjutnya dapat menggunakan mengembangkan penelitian dengan mengunakan data primer seperti kisioner atau wawancara atau observasi langsung, dan dapat mengembangkan penelitian dengan menambah varabel lain seprti profitabilitas, likuiditas, solvabilitas, laverage, rasio DSCR (Debt Service Coverage Ratio) dan lain-lain.

\section{DAFTAR PUSTAKA}

Arsa, dan Setiawina. 2015. Pengaruh Kinerja Keuangan terhadap Alokasi Belanja Modal dan Pertumbuhan Ekonomi Pemerintah Kabupaten/Kota se- Provinsi Bali Tahun 2006 s.d 2013. Jurnal Buletin Studi Ekonomi. Vol. 20 No. 2.

Halim, Abdul. 2008. Akuntansi Sektor Publik : Akuntansi Keuangan Daerah. Edisi 3. Salemba Empat: Jakarta

Peraturan Pemerintah Republik Indonesia No. 58 Tahun 2005 tentang Pengelolaan Keuangan Daerah. Jakarta

Prihastuti, Taufik dan Agusti. 2015. Pengaruh Kinerja Keuangan terhadap Alokasi Belanja Modal dan Pertumbuhan Ekonomi di Kabupaten/kota Riau. Jurnal Sorot. Volume 10 Nomor 2. 
Rosdyana, Dewi, dkk. 2015. Pengaruh Desentralisasi Fiskal Terhadap Pertumbuhan Ekonomi Daerah dan Ketimpangan Pendapatan di Pulau Jawa Tahun 2009-2013. Artikel. PESAT Universitas Gunadarma. Volume 6. ISSN 18582559

Sasana, Hadi. 2009. Peran Desentralisasi Fiskal terhadap Kinerja Ekonomi di Kabupaten/kota Provinsi Jawa Tengah. Jurnal Ekonomi Pembangunan. Vol. 10 Nomor 1.

Sujarweni, V. Wiratna. 2015. Akutansi Sektor Publik Teori, Konsep, Aplikasi. PB: Yogyakarta

Sularso, dan Restianto. 2011. Pengaruh Kinerja Keuangan Terhadap Alokasi Belanja Modal dan Pertumbuhan Ekonomi Kabupaten/kota di Jawa Tengah. Media Riset Akuntansi. Vol. 1 No. 2.

Undang-Undang Republik Indonesia No.33 Tahun 2004 tentang Perimbangan Keuangan antara Pemerintah Pusat dan Pemerintah Daerah. Jakarta

Undang-Undang Republik Indonesia No.23 Tahun 2015 tentang Keuangan Daerah. Jakarta 
